\title{
Governance Effect of Board of Directors on Banking Performance: Evidence From Tunisia
}

\author{
Sahbi Missaoui ${ }^{1} \&$ Nizar Raissi ${ }^{1,2}$ \\ ${ }^{1}$ College of Islamic Economics and Finance, Finance Department, Umm al Qura University, Makkah, KSA \\ ${ }^{2}$ Applied Research in Business Relationships and Economics (ARBRE), University of Tunis, Tunisia \\ Correspondence: Nizar Raissi, College of Islamic Economics and Finance, Finance Department, Umm al Qura \\ University, Makkah, KSA.
}

Received: January 24, 2019

Accepted: January 20, 2020

Online Published: March 19, 2020

doi:10.5430/ijfr.v11n2p358

URL: https://doi.org/10.5430/ijfr.v11n2p358

\begin{abstract}
The research tried to assess the impact of board characteristics on Tunisian bank's performance. The empirical study is based on a sample of 10 commercial banks during the period 2008-2017. Firstly, we proceed to estimate the impact of board characteristics on bank performance measured by Return on Assets (ROA) and Return on Equities (ROE) ratios. The estimation results achieved have positive and negative effects on the economic and financial bank's profitability. Hence, on the one hand, the estimate test gives a positive impact of ratio Market to book and the ratio Interest / Commissions in case of economic performance (VIC). On the other hand, these two ratios have a negative impact on performance measured by the ROE and ROA. Regarding the board and bank size, the estimate test gives a negative impact on economic profitability and a positive impact on financial profitability.
\end{abstract}

Keywords: board of directors, market to book, economic profitability, financial profitability, bank size, board size

\section{Introduction}

Several authors insist that the role of the board of directors should not be ignored. Indeed, the objective of shareholders is the maximization of wealth; this objective requires skills, trust, and absence of interest conflicts. For that, the legislator gives a determining role to the board of directors who becomes responsible of effective governance mechanisms for authority benefit, Cazalet, R.L. (2005). Becher et al. (2004) reveal that deregulation increases the need for the board. Thus, there are other effective ways of controlling the opportunistic behavior of leaders within banks. In this context, it appears that the board of directors is an obligation under the law that must meet several conditions (the presence of several members, the existence of the subcommittee, and the independence of directors...), Nikita Andrievskiy \& Elizaveta Khudko, (2015); Yulia Yelnikova, (2016). As a result, several factors (globalization, financial change, etc.) are involved in the reorganization of the structure of the banking system. Since banks provide credit to businesses, it is important to look closely at internal governance mechanisms, Barth, J.R., and al. (2001); Parrat, F. (1997, 2003).

Furthermore, the market competition influenced by governance mechanism in the way that investors will be more motivated and engaged with efficient banks, Giroud, X., \& H., Mueller, (2011). The managers and board of directors undergo a mutual monitoring that will lead to agency problem, Li, Z.F. (2018). This situation is going to clarify the strength and robustness of organizational system, Li, Z.F. (2014). The financial environment under governance approach gives more industry tournament incentives to external and internal actors, Coles, J.F. et al. (2018). The governance of board of directors allows controlling debt through risk-adjusted inside debt, Li, Z.F. et al. (2018). A numerous researchers studied the effect of factors and variables which effected the compositions of board of directions and its impact on banks performance.

The literature indicates that board of directors' financial benefits and dividend of investors that planned with managers can contribute to increase the level of stocks in market. This is due to compensation incentives and its impact to stakeholders' involvement and enhancement to increase banks income, Core, J.; Guay, W. (1999); Raissi, N. \& Missaoui, S. (2019).We will try in the following sections to detail the specifics of banking governance, different theories of governance, literature review, research methodology, findings analyses, discussion and conclusion. 


\section{Literature Review}

In large firms, shareholders cannot ensure the day-to-day management of the firm and mandate directors for this purpose. It follows a separation between ownership of capital and decision-making power. This separation has led to the divergence of interests between shareholders and managers, where the latter pursues objectives that may differ significantly from those pursued by shareholders, Nizar Raissi \& Sahbi Missaoui, (2015). To limit the opportunistic strategies of leaders and to resolve the conflicts between them, the researchers defined the system of company governance, Hanson, R.C., and Song .M.H. (2000). As such, the subject of "Corporate Governance" is currently, one of the most communicated debates; it has been recognized as one of the main issues affecting all types of firm. The concept of governance has evolved since its appearance in the late 1930s, Caprio, G.Jr., and Levine, R. (2003), Capiro, G.Jr., and al. (2007). It has attracted not only the attention of lawyers and political leaders, but also addresses issues related to the mechanisms needed to negotiate the different interests of society. It is a broad notion that covers the different ways in which individuals and groups organize themselves to achieve common goals, Berger, Allen N. and al. (2005). The debate on corporate governance, which is often theoretical, has become a reality today referred to the work of Berle and Means (1932), who are considered as the founders of governance theory. These authors discuss the separation between property and governance. Their work focuses on the consequences of the separation between risk-bearing shareholders and decision-makers on company effectiveness, Hammami, Y., Boubaker, A., (2015). Thus, the literature debate has focused differently on the notion of governance through studies advanced by Alchian A.A., and Demsetz, H. (1972) who considered the firm as a node of the contract. Whereas, Jensen and Meckling (1976), have thus concentrated on the agency theory which favors the notion of interest conflicts by taking into account information asymmetry, hence the need for the intervention of governance mechanisms. The emergence of governance has attracted the attention of many researchers dealing with firms in general and banks in particular, Donaldson, L., \& Davis, J.H. (1991). Although, this theme proves to be very important because of the rapid changes that has undergone the banking sector such as deregulation, liberalization, privatization, and the elimination of several restrictions on banking activities, Roman Snishhenko, (2016). In fact, well-governed banks are more efficient in their functions than badly governed ones, and banking crises are largely the result of bad bank governance. These crises have damaged economies, destabilized governments and intensified poverty (Levine, 2004). Moreover, banks are not assimilated to ordinary firms, since they have specificities. Indeed, they are characterized by a high opacity thus generating a strong asymmetry of information, an excessive risk taking, and separate and accentuated agency conflicts compared to other firms and by an excessively indebted capital structure, Baker M., and Gompers, P.A. (2003). Which explains the complexity of their governance system and which justifies, then, the intervention of public authorities at the level of this sector by introducing several prudential rules whose main objectives are to ensure good governance?

However, the presence of these rules, modifies the agency relationship between the shareholders and the managers, and this by the introduction of a third party which is the regulatory authority creating an asymmetry of additional information and contrary to effectiveness of bank governance mechanisms (Macey, J.R., and O'Hara, M. (2003); Fama, E. F. (1980)). The objectives of shareholders are the maximization of their wealth which cannot be among the priorities of powers. It is therefore useful to adopt a governance mechanism to strengthen its management and competitiveness, guarantee its solvency and ensure its sustainability, Zi-Yi Guo \& Yangxiaoteng Luo (2017). These governance mechanisms are divided into external and internal. According to Macey and O'Hara (2003), the impact of external governance mechanisms, in other words, market forces, is inefficient or at least limited because of the banking sector's high opacity. This gives internal mechanisms a great deal of importance in interests' equality of managers and shareholders in the banking institution, and the control mission becomes internal through the board of directors and the management, Louizi, G. (2006). Do the characteristics of the board of directors as an internal governance mechanism improves the performance of banks? The objective of the research is to determine the effect of board of directors' characteristics (independent directors, duality and the size of the board) as internal governance mechanisms on bank performance, Dang et al. (2018). To carry out the study, three hypotheses have been tested. In the first hypothesis, we tried to test the relation between performance and independent directors within the board, in other words, we checked the prediction which stipulates that an increased percentage of independent directors causes improved bank's performance. In the second hypothesis, we interested to the impact of board duality percentage on performance. Finally, in the third hypothesis, we elucidated the relationship between the importance of board of directors' size and banking performance. In order to achieve our goal, we used data in Tunisian context. Indeed, our sample is composed of ten banks listed on the stock exchange during a period of 10 years, from 2008 until 2017. Our data are extracted from annual reports of APTBEF (Tunisian Professional Association of Banks and Financial Institutions) to have the annual financial statements of banks and balance sheets at (31/12), the annual activity reports of banks and guides of the central bank. 


\section{Methodology}

The methodology of this research is based on model measured the relationship between board characteristics and bank's performance, which inspired from the various literature reviews that are interested to explain the conflicts between shareholders and managers (following the separation between owner and decision-making power). Thus, many studies are interested in solving this problem by a set of control mechanisms allowing for one hand to discipline the leaders and on the other hand to limit the extent of their power so that they manage the firm in accordance with their objectives. The objective of this section is to present an empirical work that helps to estimate the impact of boards of directors' characteristics on profitability of assets (ROA) and on the profitability of equity (ROE) in the case of Tunisian banks. To study the effect of boards of directors' characteristics on banking performance, we conduct our study with sample of ten deposit banks on Tunisian stock exchange (BVMT) as: Amen Bank, ATB, BT, BS (ATTIJBANK), BIAT, BNA, STB, UBCI, and UIB. We exclude other banks (BTS, BFT, ABC and CITIBANK) because of their small sizes, which are reflected in the weakness of their turnover and the unavailability of certain data concerning board characteristics.

The data collected from 2008 to 2017 through:

- $\quad$ The annual activity reports of banks;

- The annual reports of Tunisian Professional Association of Banks and Financial Institutions (APTBEF);

- $\quad$ Guides of Tunisian stock exchange (BVMT).

\subsection{Model Estimates and Analysis Procedures}

In this section, we will examine the effect of the board structure on bank performance. It is a question of predicting whether these characteristics of the board of directors contribute to improve bank profitability. To know the effect of these characteristics, we will first present the study variables, and then we will build the research model and analyses.

\subsubsection{The Presentation of Variables}

\subsubsection{Exogenous Variables}

- Governance variables

Admind: represents the percentage of independent directors (outside) on the board. This variable is equal to the ratio of independent directors to total number of directors. Although, the different corporate codes vary in their definitions of independent directors, a set of criteria remains common to all these definitions. According to Kassinis. G., and Vafeas, N. (2002), the independent directors are not shareholders or managers in the company, nor are they related to the managers, and more generally do not have a significant contractual relationship with the bank. This means that the number of independent directors on the board is positively correlated with performance.

TailC: The size of the board of directors is measured by the natural logarithm applied to the total of directors on the board. For some authors, the size of the board of directors is negatively related to banks performance, (Hermalin and Weisbach, 1988, 2001). Several others insisted on the positive effect of a large size. For these authors, the higher the size of the board of directors, effects greater the incentive for executives to perform better. Thus, Adams and Mehran (2003) reveal that banks with large boards have higher performance than banks with small boards.

DUAL: Duality is the appointment of the same person over the same period for the two positions of general management and board of directors, Baliga, B.R., and al., (1996). It is a dummy variable; it takes the value zero if there is not a duality and takes the value (1) if there is a duality. According to Brickley, J.A., and al. (1997) show that the combination of functions has positive effects on performance. Moreover, Fogelberg, L., and Griffith, J.M. (2000) find that duality has no impact on profitability. For Pi, L., and Timme, G. (1993) reveal that the combination of functions in banks has a negative effect on profitability.

- Control variables:

ASSETS: The bank size is measured by the natural logarithm of its asset value. Banks tend to increase their size in order to benefit from an economy of scale, which allows to increase their market shares and to have an international dimension. Thus, with the increase in competitiveness of the banking sector, financial organizations must increase their size to defend their market share. Adams and Mehran, (2003) find that performance is positively associated with bank size. It is also used by Kwan, S.H. (2003) who finds that bank size has a positive and significant effect on its profitability suggesting the existence of economies of scale.

END: This rate is measured by the ratio total receivables of customers and securities portfolios on total assets, Gorton, G., and Rosen, R. (1995). This measure has been used by several studies such as Agrawal, A., and Knoeber, C.R. (1996), Mak, Y.T., and Ong, B.P.F. (1999) and Fernandez, C. and Arrondo, R. (2005). Indeed, Grossman, S. J. and 
Hart, O. D. (1982) and Jensen, M.C. (1986) argues that debt can be used as a control mechanism of leaders. According to Altman, E.I. (1968), the most indebted firms have the lowest performance. This degradation acts in return on the level of indebtedness. The decline in performance leads to increase indebtedness.

$M T B$ : This is the market to book ratio, the ratio of market capitalization to equity. It is a financial ratio designed to define the real market value of equity. This variable is used by Wan, K-M., and al. (2012), they claim that the performance positively associated with this ratio. Assuming that there is a positive relationship between ROA-measured bank profitability and the Market to Book ratio.

VIC: This is the ratio between the interest amounts and the value of commissions. Interest and commissions are the main income of deposit banks. In addition, the intensification of competition between banks is likely to reduce the margins and revenues of bank financial intermediaries from their traditional activities. This decrease in interest margins can be offset by an increase in the proportion of commissions that are collected from the various banking transactions, excluding those relating to credit approval transactions.

Table 1. Variables related to board characteristics and control variables

\begin{tabular}{lll}
\hline Variables & Meaning & Measure \\
\hline ADEXT & Percentage of External Directors & $\begin{array}{l}\text { Number of External Directors / Total Number of } \\
\text { Directors on Board }\end{array}$ \\
\hline DUAL & $\begin{array}{l}\text { Duality Chairman of } \\
\text { Direction }\end{array}$ & Board-General \\
\hline TAILC & Size of directors board & $\begin{array}{l}\text { Binary variable equal to 1 if duality exists and if else } \\
\text { is 0 }\end{array}$ \\
\hline TAILB & Bank size & $\begin{array}{l}\text { Natural logarithm of total number of directors in } \\
\text { board }\end{array}$ \\
\hline END & Debt ratio & Natural logarithm of book value of total assets \\
\hline MTB & Ratio Market to Book & (Receivables + securities portfolios) / total assets \\
\hline VIC & Interest-Commissions & Market Capitalization / Equity \\
\hline
\end{tabular}

\subsubsection{Endogenous Variables}

The dependent variables used in econometric model are the return on equity (ROE) and the return on assets (ROA). These variables are presented as follows:

ROA: The return on assets ratio, or return on assets, is measured by the ratio of net income to total assets, and is usually expressed as economic profitability. This ratio covers all bank activities; however, it places all the assets in the same risk plan while the risks relating to the components of total assets are different. In addition, it neglects off-balance sheet activities that are gaining momentum in banking activities, (Demsetz, R.S., and Saidenberg, M.R. (1999)). The ROA has been used by many authors such as Barro, R. (1990), Angbazo, L., Narayanan, R. (1997), Xia, J.M., Yan, J.A. (2001) and Hirschey (1999).

ROE: The return on equity ratio is measured by the ratio of net income (or profit) to equity. It expresses financial profitability. This is the return from the point of view of shareholders as it highlights the return on their investments. The disadvantage of this ratio is that it can give a biased image of profitability because a high ratio can come from a low level of equity. This ratio was chosen by other researchers as Holderness and Sheehan (1988) and La Porta, R., and al. (2002).

\subsubsection{Presentation of Research Model}

$$
\mathrm{Y}_{\mathrm{it}}=\alpha+\beta_{1} \mathrm{CCADM}_{\mathrm{it}}+\beta_{2} \operatorname{ASSETS}_{\mathrm{it}}+\beta_{3} \mathrm{MTB}_{\mathrm{it}}+\beta_{4} \mathrm{END}_{\mathrm{it}}+\beta_{5} \mathrm{VIC}_{\mathrm{it}}+\varepsilon_{\mathrm{it}}
$$

With:

\begin{tabular}{|c|c|}
\hline & $\begin{array}{l}\mathrm{Y}_{\mathrm{it}} \text { : bank performance that is measured by ROE and ROA; } \\
\mathrm{i} \text { : represents the banks; }\end{array}$ \\
\hline & T: represents the study period between [2008-2017]; \\
\hline & CCADM: presents 3 measures: ADMEXT, DUAL and TAILC; \\
\hline & ASSETS: shows the bank size; \\
\hline & MTB: presents the ratio market to book; \\
\hline
\end{tabular}




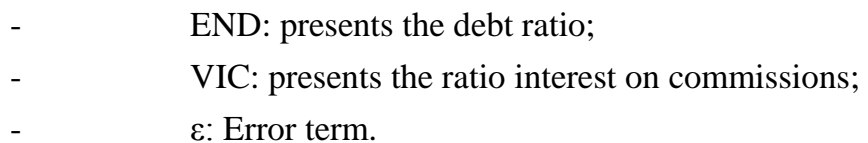

\subsection{Hypotheses}

To study the impact of board characteristics on performance, the authors make the following hypotheses:

- H1: The presence of external directors in, the board has a positive influence on bank performance (The existence of the higher percentage of external directors affected positively bank's performance.

- $\quad$ H2: duality has a negative influence on performance.

- H3: The board size has a negative influence on the banks performance, (the larger size of board causes a lower performance).

\section{Findings}

The estimation test of the model began by described exogenous and endogenous variables.

\subsection{Descriptive Statistics}

Table 2. Descriptive statistics of model

\begin{tabular}{lllll}
\hline Variables & Mean & Maximum & Minimum & Observations \\
\hline ROA & 0.0072862 & 0.0291177 & -0.1031148 & 100 \\
\hline ROE & 0.181814032 & 9.422622 & -1.764798 & 100 \\
\hline ADIND & 0.1546585 & 0.4015385 & 0 & 100 \\
\hline DUAL & 0.59 & 1 & 0 & 100 \\
\hline TAILC & 2,559328 & 2.890372 & 2.302585 & 100 \\
\hline TAILB & 14.58621 & 15.56116 & 12.9683 & 100 \\
\hline END & 0.8465298 & 7.816413 & 0.4467793 & 100 \\
\hline MTB & 1.079847 & 15.09625 & -7.763412 & 100 \\
\hline VIC & 5.657168 & 13.25776 & 3.088104 & 100 \\
\hline
\end{tabular}

According to the table above, it should be pointed out that dual management was adopted by Tunisian banks in 59\% of cases. This is due to the ability of managers to make good use of their skills to enhance banking performance. Therefore, Tunisian banks are considered small compared to commercial banks of emerging countries, (Bouslimi, J., 2015). Concerning the size of the board of directors, the listed banks have an average size of 12 members. Also, the average size of the boards of Tunisian firms belonging to other sectors of activity is 7 members, Zeghal, D.M., and al. (2006). In addition, the external directors present on average $15,46 \%$ of the board of directors. This low proportion goes back to the strict definition applied to the notion of director independence. The VIC ratio is positive, equal to 5.66. This is mainly due to the diversification and evolution of activities (the mobilization of bank balance sheets, the marketization of banking conditions, the development of off-balance sheet operations and market intermediation) at domestic and international level, which allows increasing bank commissions that enhance bank performance. Thus, we find that the debt ratio of banks is very high, which has an average of $84.65 \%$. Tunisian commercial banks make a massive use of indebtedness to provide loans to economic agents with a need for financing. This intense debt is also explained by the important role of financial intermediation. Between 1990 and 1999, their average financial intermediation rate was $71 \%$. The specificity of Tunisian bank governance appears in the large size of the board of directors and in the highest debt ratio. According to the descriptive statistics reported in table (2), during the period 2008-2017, Tunisian banks recorded averages of $0.73 \%$ for the ROA and $18.18 \%$ for the ROE. According to 150 observations from 1990 to 2004 of a sample of Tunisian commercial banks, found an average of $0.89 \%$ for the ROA and $12.01 \%$ for the ROE, (Central Bank of Tunisia, 2009, Gargouri, I., (2013)).

\subsection{The Model Estimation}

To study the impact of the board of directors characteristics on Tunisian bank's performance, it used panel data econometrics. Panel data econometrics helps to study the interaction between the real sphere and the financial sphere. Panel data has two dimensions: one for individuals and one for time (in a period from 2008 to 2017). They are generally indicated by the index $i$ and t respectively (i: Tunisian banks, t: from 2008 to 2017). It is often interesting to identify the effect associated with each bank, an effect that does not vary over time, but that varies from one individual to another. This effect can be fixed or random. Thus, the panel data are particularly interested in the heterogeneity 
between individuals (banks). Further advantages can be brought to the use of panel data over cross-sectional or chronological data, (Hsiao (2003)). Panel data generally exhibit less multicollinearity than sectional data or time series data and allow for more accurate estimates of parameters. Indeed, for our case of empirical validation research that investigates the impact of board characteristics on the performance of Tunisian commercial banks from 2008 to 2017, we used the data method of the panel. So, using this method allows us to check the model nature that can be fixed or random. However, the application of the Ordinary Least Squares (OLS) method for regressions is inappropriate. This is due to the special nature of the pooling variables that are doubly indexed (time, individual). This estimation method, OLS, does not adequately present the specific effect of each individual. Taking into account, in a way of this specific effect, which presents the same for all the individuals, just inflates and overestimates the variance of OLS estimators. These are neither precise nor BLUE (Best Liner Unbiased Estimator). Therefore, a BLUE estimator can be constructed from the Generalized Least Squares (GLS) estimate that is most appropriate for removing the inaccuracy of the Ordinary Least Squares (OLS) method. The question is then which model, among the models with random effects and fixed effects must be retained. This will lead us to present the Hausman test (1978) which is the standard test for the specification of individual effects. The Hausman test is a specification test that determines whether the coefficients of the two estimates (fixed and random) are statistically different. The idea of this test is that under the null hypothesis of independence between the errors and the explanatory variables, the two estimators are unbiased, so the estimated coefficients should be slightly different. So, this test allows the search for the possible existence of a correlation or a lack of specialization, that is to say, if the $\alpha_{\mathrm{i}}$ are random, then there is a good chance that they are correlated some $\mathrm{X}_{\mathrm{it}}$. The hypothesis tested by Hausman concerns the correlation of individual effects and explanatory variables are presented as follows:

$\mathrm{H}_{0}: \mathrm{E}\left(\alpha_{\mathrm{i}} / \mathrm{X}_{\mathrm{i}}\right)=0$

$\mathrm{H}_{1}: \mathrm{E}\left(\alpha_{\mathrm{i}} / \mathrm{X}_{\mathrm{i}}\right) \neq 0$

The distinction between these two hypotheses is realized by the following way:

According to the null hypothesis $\mathrm{HO}$ of specification, this statistic is asymptotically distributed according to a Chi 2 with $\mathrm{k}$ degrees of freedom. So if the realization of the statistic $\mathrm{H}$ is greater than the threshold of $\alpha \%$, we reject the null hypothesis and we therefore privilege the adoption of fixed individual effects H1. Our estimate was made using panel data with the Stata software. The results are presented in the following tables:

Table 3. Result of Hausman-specific tests

\begin{tabular}{lllll}
\hline & OLS & \multicolumn{3}{l}{ Panel Data } \\
\hline & ROA & ROE & ROA & ROE \\
\hline Constant & 0.0958 & -0.998 & 0.1009 & -1.3808 \\
& $(1.71)^{*}$ & $(-0.40)^{*}$ & $(1.28)^{*}$ & $(-0.40)^{*}$ \\
\hline ADIND & -0.02229 & 1.2813 & -0.0326 & 1.3189 \\
& $(-1.58)^{*}$ & $(1.24)^{*}$ & $(-1.66)^{*}$ & $(1.49)^{*}$ \\
\hline DUAL & -0.0037 & -0.2226 & -0.0003835 & -0.2159 \\
& $(-1.40)^{*}$ & $(-1.49)^{*}$ & $(-0.07)^{*}$ & $(-0.94)^{*}$ \\
\hline TAILC & -0.08119 & 0.05594 & -0.007327 & 0.0804 \\
& $(-2.73)^{*}$ & $(0.16)^{*}$ & $(-0.39)^{*}$ & $(0.10)^{*}$ \\
\hline TAILB & -0.00349 & 0.0952 & -0.005567 & 0.114 \\
& $(-1.73)^{*}$ & $(0.65)^{*}$ & $(-1.23)^{*}$ & $(0.50)^{*}$ \\
\hline END & 0.00043 & -0.0474 & -1.0004646 & -0.0306 \\
& $(0.89)^{*}$ & $(-1.44)^{*}$ & $(-0.19)^{*}$ & $(-0.22)^{*}$ \\
\hline MTB & 0.00324 & -0.2537 & 0.0030663 & -0.25529 \\
& $(1.09)^{*}$ & $(-0.98)^{*}$ & $(3.90)^{*}$ & $(-5.19)^{*}$ \\
\hline VIC & 0.001923 & -0.0185 & 0.0015374 & -0.016 \\
& $(2.03)^{*}$ & $(-0.52)^{*}$ & $(1.28)^{*}$ & $(-0.26)^{*}$ \\
\hline Observation number & 100 & & & \\
\hline $\mathrm{R}^{2}$ within & $24.94 \%$ & $27.15 \%$ & $20.68 \%$ & $24.39 \%$ \\
\hline $\mathrm{R}^{2}$ between & & & $27.56 \%$ & $58.84 \%$ \\
\hline $\mathrm{F}_{\text {calculated }}$ & $(5.17)^{* *}$ & $(1.62)^{* *}$ & $(24.33)^{* *}$ & $(32.69)^{* *}$ \\
\hline Hausman & & & 0.9812 & 0.9986 \\
\hline $\mathrm{X}^{2}(\mathrm{k})$ at 95\% & 14.067 & 14.067 & 14.067 & 14.067 \\
\hline${ }^{*}$ t of student; ${ }^{* *} \mathrm{~F}(7.92)$ & & & & \\
\hline
\end{tabular}


From this table, it can be seen from the Fisher model statistic ROA that $\mathrm{F}_{\text {cal }}=24.33>>1.96$, leads us to say that the model is globally significant. In addition, the Fisher model statistic of ROE equals $F_{\text {cal }}=32.69>>1.96$, so the model is globally significant.

According to the Hausman test (1978), we have:

- $\quad$ K: represents the number of exogenous variables that equals 7

- $\quad$ Chi square to five degree of freedom (14.067)

- The specification statistic of Hausman $\mathrm{H}$

- $\quad$ H0: the model specifies with random individual effects

- $\quad$ H1: the model specifies with fixed individual effects.

At $95 \%$, the Hausman statistic is less than the chi two to 5 degrees of freedom, so we reject the hypothesis H1, so the model is specified with random individual effects.

Table 4. Results of model regression

\begin{tabular}{lllll}
\hline \multicolumn{5}{l}{ Dep. variables } \\
\hline & Sign & ROA & Sign & ROE \\
\hline Ind. variables & & & & \\
\hline C & $?$ & 0.199 & $?$ & 0.693 \\
\hline ADIND & - & 0.097 & + & 0.136 \\
\hline DUAL & - & 0.947 & - & 0.346 \\
\hline TAILC & - & 0.698 & + & 0.924 \\
\hline TAILB & - & 0.220 & + & 0.616 \\
\hline END & - & 0.850 & - & 0.823 \\
\hline MTB & + & 0.000 & - & 0.000 \\
\hline VIC & + & 0.200 & - & 0.793 \\
\hline
\end{tabular}

\subsubsection{Effect of the Characteristics of Board of Directors on Banks Performance Measured by ROA}

The first model adopts the ROA performance measure as the explained variable. The results of the regression are shown in table 4.

$$
\mathrm{ROA}_{\mathrm{it}}=\alpha+\beta_{1} \mathrm{ADMEXT}_{\mathrm{it}}+\beta_{2} \mathrm{DUAL}_{\mathrm{it}}+\beta_{3} \mathrm{TAILC}_{\mathrm{it}}+\beta_{4} \mathrm{ACTIF}_{\mathrm{it}}+\beta_{5} \mathrm{MTB}_{\mathrm{it}}+\beta_{6} \mathrm{END}_{\mathrm{it}}+\beta_{7} \mathrm{VIC}_{\mathrm{it}}+\varepsilon_{\mathrm{it}}
$$

Contrary to the agency theory, the coefficient of the number of independent directors is negative. The presence of independent directors on boards of banks helps to reduce banks' performance. Similarly, Adams and Mehran (2003) and Bhagat and Black (2002) state that independent director:

- $\quad$ are not effective in controlling leaders.

- $\quad$ these members are not able to understand the complexity of each bank's activities.

- $\quad$ are not effective at resolving internal agency conflicts.

- $\quad$ are not efficient to fulfill their main role, namely the discipline of leaders.

In this case, it can be considered that the supervisory role of Tunisian banks' leaders is attributed to the regulatory and supervisory authorities (including the central bank) which enact several prudential rules to be respected by all banks and ensure their application. To conclude, in accordance with the results of Prowse, S. (1997), we can say that board independence is an inefficient means in the discipline of bank executives, which explains the complexity of banking activities which is an obstacle to the directors (Independent to be informed about the state of the bank). This result undermines our assumption that independent directors have a positive impact on performance. Other authors such as Baysinger and Bulter (1985), board independence are an effective means of controlling leaders. In addition, Brickley and al., (1997) and Weibasch (1988) argue that this mechanism is effective for management discipline and improves profitability. A first reading shows that the coefficient of duties cumulation of board chairman and general manager is negative and statistically insignificant. According to agency theory, the results obtained show a negative relation 
between the duality and the banking performance measured by ROA, Bancel, F. (1997). These results can be explained by the fact that the manager has not properly exploited his experience in banking and his very specific knowledge of it that can be useful for decision-making and subsequently increase his performance. In general terms, the monumental structure (combination of functions) makes it difficult to identify the respective responsibilities of board chairman and the chief executive officer (CEO) in the event of poor performance by the bank. Thus for Pi, L., and Timme, G. (1993), following their study of the US banking sector, conclude that the return on assets is higher in the banks that separated the functions of board chairman and the CEO of a bank (Compared to that which combine the two functions). The explanation lies in the fact that the leader who is at the same time the chairman of the board still wants to protect his power position and makes decisions that involve less risk. Therefore, the studies of Boyd (1995) and Simpson, W. Gary \& Gleason, Anne E. (1999) find that duality has a negative impact on performance; this result confirms our hypothesis (H2). Regarding the board size, according to the predictions of agency's theorists, the high board size favors the dominance of leaders by creating coalitions and group conflicts, Godard, L. (2001). Thus, the negative effect of board size on performance of Tunisian banks is due to the increase of surveillance capacity and can also lead to a difficulty of communication and decision-making. This result confirms our assumption that board size (TAILC) has a negative effect on the performance of Tunisian commercial banks; this result is invalid to that found by Belkhir (2010). Indeed, the control of managers in a bank has a higher board size make their control very difficult. So, for the significance, Wintoki (2007), found no significant relationship between the size of the board and performance. For control variables, we note that the bank size measured by the total assets has a negative and statistically insignificant impact on the profitability measured by ROA; if bank size is smaller, then its performance is better. Boyd and Runkle (1993) similarly conclude that following the introduction of deposit insurance schemes, managers can engage in activities at high risk levels in order to increase their earnings while increasing the bank size. However, performance could decline with the increase in bad debts and potential losses. This is consistent with the results of Bassett and Brady (2001) which are based on a sample of banks in the United States between 1985 and 2000; these two authors note that small banks (from their assets) are more efficient than large ones. According to them, the reason is that small banks have higher rates of return on their loans. Some others find that bank size has a positive and significant effect on bank profitability suggesting the existence of economies of scale. In addition, the debt ratio has a negative and insignificant impact on Tunisian bank performance, measured by ROA ratio. This means that a financial structure marked by high indebtedness makes the financial bank very important and reduces net profit and subsequently the book yield. For the ratio market to book, this ratio has a positive and statistically significant impact on the performance of Tunisian banks measured by ROA ratio. For the ratio of interest on commissions has non-significant relationship with performance, which explains the risks borne by the banks following the development of new activities (market intermediation) carrying new risks.

\subsubsection{Effect of Board Characteristics on Bank Performance Measured by ROE}

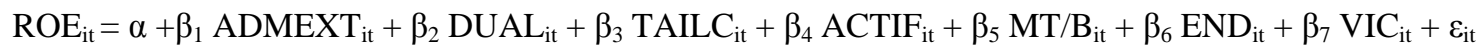

The second model adopts the ROE performance measure as an explanatory variable. The regression results are shown in table 4. Firstly, there is a positive and insignificant correlation between the percentage of independent directors and the banking performance measured by ROE. This positive relationship is consistent with the work of Mishra and Nielsen (2000), which is based on a sample of the 100 largest US holding banks and commercial banks, observed from 1982 to 1989. The positive impact can be explained by their appreciable human capital and their reputation in the labor market, (Singh, M., and Davidson III, W.N. (2003)). Thus, for Weisbach (1988) and Brickley et al. (1997); the existence of independent directors on the board is very necessary to constitute an effective governance mechanism in order to control the managers and improve the performance of banks, through their strategic decisions and their pressure to dismiss the non-performing managers. But, it is worth noting the insignificant effect on the percentage of independent directors on bank profitability. This is due to the complexity of banks' activities where they become unable to understand the state of the bank. For duality, their negative impact on the return on equity of Tunisian banks is explained by:

- The accentuation of agency costs (impartiality of control, ambiguity of responsibilities, conflicts of interest, imbalances of power, asymmetry of information, etc.).

- Weakens of board effectiveness.

While the board size has a positive and statistically insignificant impact. This result corroborates the conclusions of some authors, that the smaller board can be easily controlled and influenced by the executive, while the large board presents a variety of board-specific experiences that can managers to pursue their own interests, (Simpson, W. Gary \& Gleason, Anne E. (1999)). This result also corroborates the findings of Adams and Mehran (2003) who found that 
banks with large boards perform better than banks with small boards. This is also the case of debt, the ratio of which has a negative impact on the return on equity of Tunisian banks. This result can support the same above interpretations. For the market to book ratio, there is a negative and statistically significant relationship on asset profitability. Moreover, for the interest-to-commission ratio, we note the existence of the negative impact of this ratio on the return on equity measured by the ROE, which is explained by the risk borne by Tunisian banks following diversification and evolution of their internal and external activities (market intermediation).

\section{Discussion and Conclusion}

The field of corporate governance was formed mainly by Berle and Means (1932) who discussed the problem of ownership separation and decision-making power. Thus, Charreaux $(1997,2000)$ defines the concept of corporate governance. The term governance is a very broad term; it concerned the company in first place and spread to banks. The latter occupies a central place in the world economy following economic developments, liberalization and deregulation. Indeed, good governance is a brake for banks to take an unjustified risk taking by allowing them to better adapt to the new deregulated environment, Black, B.S., and al. (2006). It is for this reason that we have chosen our research concerning governance and performance. So the purpose of this research is to study the relationship between board characteristics and performance. Thus, the results of regression according to the method of panel data due to superiority over other method. This method takes into account the heterogeneity of individuals. We conclude that the presence of external independent directors seems to have a negative impact on accounting performance, these results are consistent with literature, notably Yermack (1996) and Agrawal, A., and Knoeber, C.R. (1996) who find that firms with a large number of external directors have a low book value. Thus, Song, H.Y., et al. (2001) state that the number of independent directors, their average age and the length of their mandates do not affect bank performance. Therefore, Nam, S. (2004) states that external directors are the most influential and only they can ensure that banks apply the regulations specific to their activities and that managers do not have discretionary behaviors that undermine the wealth of shareholders. However, the results of this regression show the existence of a non-significant relationship between board size with economic and financial performance. These results are in line with the literature, in particular the work of Simpson, W. Gary \& Gleason, Anne E. (1999), who reveal that the size of the board does not have a significant effect on the probability of banks going bankrupt. Thus, Belkhir (2007) reveals that the size of the board of directors does not affect banking performance. Also, several others like Adams and Mehran (2003) reveal that banks having large councils are the ones that have the highest performances than the banks having small councils. As for duality, it does not have a significant effect on economic and financial performance. Indeed, this result corroborates that of Rechner, P.L. \& Dalton, D.R. (1991) which states that the combination of officer functions and board chairman does not have an effect on the performance of American companies. Thus, Vafeas, N. (2000) confirms this result on a sample of British firms. Indeed, this negative relationship is due to the decrease in the control exercised by the Board of Directors over the CEO. In the same way duality can constitute a means of rooting of leaders and subsequently a source of deterioration of performance. This result invalidates the work of Cannella and Lubtakin, (1993); and Sridharan, U.V., and Marsinko, A. (1997) who argued that duality positively influence performance. The results of our study concerning the effect of characteristics of the board of directors on the banking performance measured by ROA and ROE of Tunisian banks are confirmed by some and reversed by others. This contradiction can be explained both by the lack of attention to the delayed effects of variables characterizing the board of directors, by the absence of context or control variables. However, the influence of certain variables on performance is conditioned by a series of factors such as the ownership structure, the capacity and the reputation of leaders (Andert, D., and al. (2011)) or the sector of activity (Opler and Titman, 1994; Pastré, O. 1994).

\section{References}

Adams, R., \& Mehran, H. (2003). Board structure, banking firm performance and the bank holding company organizational form. Proceedings of Federal Reserve Bank of Chicago No. 866, 408-422.

Agrawal, A., \& Knoeber, C. R. (1996). Firm Performance and Mechanisms to Control Agency Problems between Managers and Shareholders. Journal of Financial and Quantitative Analysis, 31(3), 377-397. https://doi.org/10.2307/2331397

Alchian A. A., \& Demsetz, H. (1972). Production, Information Costs, and Economic Organization. The American Economic Review, 62(5), 777-795.

Altman, E. I. (1968). Financial ratios, discriminant analysis and the prediction of corporate bankruptcy. The Journal of Finance, 23(4), 589-609. https://doi.org/10.1111/j.1540-6261.1968.tb00843.x 
Andert, D., Platt, A., \& Alexakis, G. (2011). Alternative, Grassroots, And Rogue Leadership: A Case For Alternating Leaders In Organizations. Journal of Applied Business Research, 27(2), 53-61. https://doi.org/10.19030/jabr.v27i2.4139

Andrievskiy, N., \& Khudko, E. (2015, March). Financial Markets In February 2015. Russian Economic Developments, Gaidar Institute for Economic Policy, 3, 13-17. https://doi.org/10.2139/ssrn.2587134

Angbazo, L., \& Narayanan, R. (1997). Top Management Compensation and the Structure of the Board of Directors in Commercial Banks. Review of Finance, 1(2), 239-259. https://doi.org/10.1023/A:1009760306445

Baker, M., \& Gompers, P. A. (2003). The Determinants of Board Structure at the Initial Public Offering. The Journal of Law and Economics, 46(2), 569-598. https://doi.org/10.1086/380409

Baliga, B. R., Moyer, R. C., \& Rao, R. (1996). CEO Duality, Firm Performance and Corporate Governance: What's the Fuss?. Strategic Management https://doi.org/10.1002/(SICI)1097-0266(199601)17:1<41::AID-SMJ784>3.0.CO;2-\#

Bancel, F. (1997). La gouvernance des enterprises. Ed. Economica. Banque et marché, 66, 47-51.

Barro, R. (1990). Government spending in a simple model of endogenous growth. Journal of Political Economy, 98, 103-117. https://doi.org/10.1086/261726

Barth, J. R., Gerard, C. Jr., \& Ross, L. (2001). The regulation and supervision of banks around the world: a new database. In R. E. Litan \& R. Herring (Eds.), Brooking-Wharton Papers on Financial Services (pp. 183-250). Washington, DC, Brookings Institution. https://doi.org/10.1353/pfs.2001.0003

Bassett, W. F., \& Brady, T. F. (2001). The Economic Performance of Small Banks, 1985-2000 (pp. 719-728). Federal Reserve Bulletin, Board of Governors of the Federal Reserve System.

Baysinger, B. D., \& Butler, H. N. (1985). Corporate Governance and the Board of Directors: Performance Effects of Changes in Board Composition. Journal of Law, Economics, \& Organization, 1, 101-124.

Becher, H., Müller, O., Jahn, A., Gbangou, A., Kynast-Wolf, G., \& Kouyaté, B. (2004). Risk factors of infant and child mortality in rural Burkina Faso. Bull World Health Organ, 82(4), 265-73.

Belkhir, M. (2010). Board structure, ownership structure and firm performance: evidence from banking. Applied Financial Economics, 19(19), 1581-1593. https://doi.org/10.1080/09603100902967561

Berger, A. N., \& Clarke, G. R. G., Cull, R., Klapper, L., \& Udell, G. F. (2005). Corporate governance and bank performance: a joint analysis of the static, selection, and dynamic effects of domestic, foreign, and state ownership. Policy Research Working Paper Series 3632, The World Bank. https://doi.org/10.1596/1813-9450-3632

Berle, A., \& Means, G. (1932). The Modern Corporation and Private Property. Commerce Clearing House, New York.

Bhagat, S., \& Black, B. (2002). The Non-Correlation between Board Independence and Long-Term Firm Performance. Journal of Corporation Law, 27, 231-273.

Black, B. S., Jang, H., \& Kim, W. (2006). Does corporate governance predict firms' market values? Evidence from Korea. Journal of Law, Economics, and Organization, 22(2), 366-413. https://doi.org/10.1093/jleo/ewj018

Bouslimi, J. (2015). From Governance to the Efficiency of the Tunisian Banks. International Journal of Financial Economics, 4(3), 160-175.

Boyd, B. K. (1995). CEO duality and firm performance: A contingency model. Strategic Management Journal, 16(4), 301-312. https://doi.org/10.1002/smj.4250160404

Boyd, J. H., \& Runkle, D. E. (1993). Size and performance of banking firms: Testing the predictions of theory. Journal of Monetary Economics, 31(1), 47-67. https://doi.org/10.1016/0304-3932(93)90016-9

Brickley, J. A., Jeffrey, L. C., \& Jarrell, G. (1997). Leadership structure: Separating the CEO and Chairman of the Board. Journal of Corporate Finance, 3, 189-220. https://doi.org/10.1016/S0929-1199(96)00013-2

Cannella, A. A. Jr., \& Lubatkin, M. (1993). Succession as a Sociopolitical Process: Internal Impediments to Outsider Selection. The Academy of Management Journal, 36(4), 763-793. https://doi.org/10.2307/256758

Capiro, G. Jr., Laeven, L., \& Levine, R. (2007). Governance and bank valuation. Journal of Financial Intermediation, 16, 584-617. https://doi.org/10.1016/j.jfi.2006.10.003 
Caprio, G. Jr., \& Levine, R. (2003). Corporate governance of banks: concepts and internationals observation. Working paper, No. 10158, National bureau of economic research (NBER).

Cazalet, R. L. (2005). Genèse et évolution de la gouvernance d'entreprise. 5eme colloque international de l'ITEC et la FIDEF, gouvernance d'entreprise: dimensions culturelles, économiques et sociale (pp. 1-37). MA, Tunis.

Charreau, G. (2000). Le conseil d'administration dans les théories de la gouvernance. Revue du Financier, 127, 6-15.

Charreaux, G. (1997). Le gouvernement d'entreprise: Corporate Governance, Théories et Faits (p. 540). Paris, Economica, ouvrage collectif.

Charreaux, G. (2000). Le conseil d'administration dans les théories de la gouvernance. Working Papers CREGO 001201, Université de Bourgogne - CREGO EA7317 Centre de recherches en gestion des organisations.

Coles, J. F., Li, Z. F., \& Wang, A. Y. (2018). Industry tournament incentives. Rev. Finance. Stud, 31(4), 1418-1459. https://doi.org/10.1093/rfs/hhx064

Core, J., \& Guay, W. (1999). The use of equity grants to manage optimal equity incentive levels. J. Account. Econ, 28, 151-184. https://doi.org/10.1016/S0165-4101(99)00019-1

Dang, C. Y., Li, Z. C., \& Yang, C. (2018). Measuring firm size in empirical corporate finance. Journal of Banking \& Finance, 86(C), 159-176. https://doi.org/10.1016/j.jbankfin.2017.09.006

Demsetz, R. S., \& Saidenberg, M. R. (1999). Looking beyond the CEO: Executive compensation at banks. Staff reports 68, Federal Reserve Bank of New York. https://doi.org/10.2139/ssrn.163172

Donaldson, L., \& Davis, J. H. (1991). Stewardship Theory or Agency Theory: CEO Governance and Shareholder Returns. Australian Journal of Management, 16, 49. https://doi.org/10.1177/031289629101600103

Fama, E. F. (1980). Agency Problem and the Theory of The Firm. Journal of Political Economics, 40, 163-181. https://doi.org/10.1086/260866

Fernandez, C., \& Arrondo, R. (2005). Alternative internal controls as substitute of the board of directors. Corporate Governance: An International Review, 13(6), 856-866. https://doi.org/10.1111/j.1467-8683.2005.00476.x

Fogelberg, L., \& Griffith, J. M. (2000). Journal of Financial and Strategic Decisions: Control and Bank Performance. Journal of Financial and Strategic Decisions, 13(3), 63-69.

Gargouri, I. (2013). Efficiency of Tunisian Commercial Banks According to the Intermediation Approach. International Journal of Economics and Finance, 5(5),190-203. https://doi.org/10.5539/ijef.v5n5p190

Giroud, X., \& Mueller, H. (2011). Corporate Governance, Product Market Competition, and Equity Prices. Journal of Finance, 66, 563-600. https://doi.org/10.1111/j.1540-6261.2010.01642.x

Godard, L. (2001). La Taille du Conseil d'administration: Determinants et Impact sur la Performance. Cahier du FARGO, No 1010702.

Gorton, G., \& Rosen, R. (1995). Corporate control, portfolio choice and the decline of banking. Journal of Finance, 50(5), 1377-1420. https://doi.org/10.1111/j.1540-6261.1995.tb05183.x

Grossman, S. J., \& Hart, O. D. (1982). Corporate Financial Structure and Managerial Incentives. In McCall, J. J. (Ed.), The Economics of Information and Uncertainty. University of Chicago Press.

Guo, Z.-Y., \& Luo, Y. X. T. (2017, June). Credit Constraint Exports in Countries with Different Degrees of Contract Enforcement. Business and Economic Research, Macrothink Institute, 7(1), 227-241. https://doi.org/10.5296/ber.v7i1.10923

Hammami, Y., \& Boubaker, A., (2015). Ownership structure and bank risk-talking: Empirical evidence from the Middle East and North Africa. International Business Research, 8(5), 271-284. https://doi.org/10.5539/ibr.v8n5p271

Hanson, R. C., \& Song, M. H. (2000). Managerial ownership, board structure, and the division of gains. Journal of Corporate Finance, 6, 55-70. https://doi.org/10.1016/S0929-1199(99)00013-9

Hausman, J. A. (1978). Specification Tests in Econometrics. Econometrica, 46, 1251-1271. https://doi.org/10.2307/1913827

Hermalin, B. E., \& Weisbash, M. S. (1988).The determinants of board composition. Hand Journal of Economics, 19(4), 589-606. https://doi.org/10.2307/2555459 
Hermalin, B. E., \& Weishbach, M. S. (2001). Board of directors as an endogenously determined institution: A survey of the economic literature. NBER working paper series, WP No.8161, 1-41. https://doi.org/10.3386/w8161

Hirschey. (1999). Managerial equity ownership and bank performance. Economic Letters, 64, 209-2013. https://doi.org/10.1016/S0165-1765(99)00082-8

Holderness, C. G., \& Sheehan, D. P. (1988). The role of majority shareholders in publicly held corporations: An exploratory analysis. Journal of Financial Economics, 20(1-2), 317-346. https://doi.org/10.1016/0304-405X(88)90049-9

Hsiao, C. (2003). Analysis of Panel Data. Cambridge University Press, Cambridge. https://doi.org/10.1017/CBO9780511754203

Jensen, M. C. (1986). Agency Costs of Free Cash Flow, Corporate Finance, and Takeovers. The American Economic Review, 76(2).

Jensen, M. C., \& Meckling, W. H. (1976). Theory of the firm: managerial behavior, agency costs, and ownership structure. Journal of Financial Economics, 3(4), 305-360. https://doi.org/10.1016/0304-405X(76)90026-X

Kassinis, G., \& Vafeas, N. (2002). Corporate boards and outside stakeholders as determinants of environmental litigation. Strategic Management, 23(5), 399-415. https://doi.org/10.1002/smj.230

Kwan, S. H. (2003). Operating performance of banks among Asian economies: An international and time series comparison. SSRN Electronic Journal, 27(3), 471-489. https://doi.org/10.1016/S0378-4266(02)00384-9

La Porta, R., Lopez-De-Silanes, F., \& Shleifer, A. (2002). Government ownership of banks. Journal of Finance, 57(1), 265- 301. https://doi.org/10.1111/1540-6261.00422

Levine, R. E. (2004). The Corporate Governance of Banks - a concise discussion of concepts and evidence. Policy Research Working Paper Series 3404, The World Bank. https://doi.org/10.1596/1813-9450-3404

Li, Z. F. (2014). Mutual monitoring and corporate governance. J. Bank. Finance, 45, 255-269. https://doi.org/10.1016/j.jbankfin.2013.12.008

Li, Z. F. (2018). Mutual Monitoring and Agency Problem. Retrieved 11 January 2020, from https://www.researchgate.net/publication/272305464_Mutual_Monitoring_and_Agency_Problems

Li, Z. F., Lin, S., Sun, S., \& Tucker, A. (2018). Risk-adjusted inside debt. Glob. Finance. J., 35, 12-42.

Louizi, G. (2006). Impact du conseil d'administration sur la performance des banques tunisiennes. Working paper (pp. 1-38), XVème Conférence Internationale de Management Stratégique, Annecy / Genève.

Macey, J. R., \& O’Hara, M. (2003). The Corporate Governance of Banks. Economic Policy Review, 9(1),

Mak, Y. T., \& Ong, B. P. F. (1999). Changes in Ownership Structure and Board Structure after an Initial Public Offering. National University of Singapore (NUS), Working Paper No. Mak 1.

Mishra, C., \& Nielsen, J. F. (2000). Board Independence and Compensation Policies in Large Bank Holding Companies. Financial Management, 29(3), 1-23. https://doi.org/10.2307/3666229

Nam, S. (2004). Relationship banking and its role in corporate governance. Research Paper Series, 56. ADB Institute.

Opler, T. C., \& Titman, S. (1994). Financial Distress and Corporate Performance. The Journal of Finance, 49(3), 1015-1040. https://doi.org/10.1111/j.1540-6261.1994.tb00086.x

Parrat, F. (1997). La gouvernance d'entreprise. Maxima, Paris.

Parrat, F. (2003). Le Gouvernement d'entreprise. Dunod; Édition : Nouvelle.

Pastré, O. (1994). Le Gouvernement d'entreprise : questions de méthodes et enjeux théoriques. Revue d'Economie Financière, 31, 15-32. Corporate governance: Le gouvernement d'entreprise.

Pi, L., \& Timme, G. (1993). Corporate control and bank efficiency. Journal of Banking \& Finance, 17(2-3), 515-530.

Prowse, S. (1997). Corporate control in commercial banks. The Journal of Financial Research, 20(4), 509-527.

Raissi, N., \& Missaoui, S. (2015). Role of investor sentiment in financial markets: an explanation by behavioural finance approach. International Journal of Accounting and Finance, 5(4), 362-401.

Raissi, N., \& Missaoui, S. (2019). Understanding Investor Biased Reaction and Financial Decision Making. International Journal of Business and Management Invention (IJBMI), 8(03), 34-49. 
Rechner, P. L., \& Dalton, D. R. (1991). CEO duality and organizational performance: A longitudinal analysis. Strategic Management Journal, 12, 155-160. https://doi.org/10.1002/smj.4250120206

Simpson, W. G., \& Gleason, A. E. (1999). Board structure, ownership, and financial distress in banking firms. International Review of Economics \& Finance, 8(3), 281-292. https://doi.org/10.1016/S1059-0560(99)00026-X

Singh, M., \& Davidson III, W. N. (2003). Agency costs, ownership structure and corporate governance mechanisms. Journal of Banking \& Finance, 27, 793-816. https://doi.org/10.1016/S0378-4266(01)00260-6

Snishhenko, R. (2016, September). System of Financial Security as a Tool of Financial Market Participant. Accounting and Finance, Institute of Accounting and Finance, 3, 95-101.

Song, H. Y., Liu, Z. N., \& Jiang, P. (2001). Analysing the determinants of China's aggregate investment in the reform period. China Economic Review, 12, 227-242. https://doi.org/10.1016/S1043-951X(01)00052-9

Sridharan, U. V., \& Marsinko, A. (1997). CEO duality in the paper and forest products industry. Journal of Financial Economic, 10(1), 59-65.

Vafeas, N. (2000). Board structure and the informativeness of earnings. Journal of Accounting and Public Policy, 19(2), 139-160. http:// doi.org/10.1016/S0278-4254(00)00006-5

Wan, K. M., Guthrie, K., \& Sokolowsky, J. (2012). CEO Compensation and Board Structure Revisited - A Rejoinder. Comments and Discussions of the Journal of Finance. https://doi.org/10.2139/ssrn.2084630

Weisbach, M. S. (1988). Outside directors and CEO turnover. Journal of Financial Economic, 20, 431-460.

Wintoki, M. B. (2007). Corporate Boards and Regulation: The Effect of the Sarbanes-Oxley Act and the Exchange Listing Requirements on Firm Value. Journal of Corporate Finance, 13, 229-250.

Xia, J. M., \& Yan, J. A. (2001). Clarifying some basic concepts and results in arbitrage pricing theory.

Yelnikova, Y. (2016). Relationship Derivatives Financial Markets, Money And Stock Markets As A Subsystem Of Financial Market. Baltic Journal of Economic Studies, 2(1). https://doi.org/10.30525/2256-0742/2016-2-1-39-45

Yermack, D. (1996). Higher market valuation of companies with a small board of directors. Journal of Financial Economics, 40, 185-211. https://doi.org/10.1016/0304-405X(95)00844-5

Zeghal, D. M., Chtourou, S. M., \& Fourati, Y. M. (2006). Impact de la structure de propriété et de l'endettement sur les caractéristiques du Conseil d'administration: Etude empirique dans le contexte d'un pays émergent, papier de recherche, 27ème Congrès de l'Association Francophone de Comptabilité (pp 1-30). 